\title{
The Value of Iron Metabolism Dynamic Changes in Response to Direct Anti-Viral Agents among Egyptian Chronic HCV Patients \\ Assem El-Sherif ${ }^{1}$, Fathy G. Abd El-Razek ${ }^{1}$, Mohammed S. Hussein ${ }^{1}$, Mohammed El Shorbagy ${ }^{2}$, Ahmed Eliwa $^{1 *}$, Mohamed El Kassas ${ }^{3}$ \\ ${ }^{1}$ Internal Medicine Department, Faculty of Medicine, Al-Azhar University, Cairo, Egypt. \\ ${ }^{2}$ Clinical Pathology Department, Faculty of Medicine, Al-Azhar University, Cairo, Egypt. \\ ${ }^{3}$ Endemic Medicine Department, Faculty of Medicine, Helwan University, Cairo, Egypt. \\ *Corresponding author: Ahmed Eliwa, Mobile: (+20)01094044973, E-Mail: ahmedmahereliwa@ yahoo.com.
}

\begin{abstract}
Background: Like other viruses, hepatitis $\mathrm{C}$ virus (HCV) needs constituents of host cells to proliferate and iron is considered as one of the most important constituents. So, chronic HCV often appears to be associated with disturbances in iron homeostasis. Objective: The aim of this study was to evaluate the iron metabolism dynamic changes in response to direct antiviral agents (DAAs) among Egyptian chronic HCV patients.

Patients and Methods: This prospective cohort study was conducted on 180 subjects, 150 of them had chronic HCV whom received different DAAs regimens at one of the specialized HCV treatment facilities (Group A), as well as another 30 healthy volunteers (Group B), in the period from January 2017 to September 2018. The study was approved by the medical ethics committee of Al-Azhar University Hospitals and a written informed consent was obtained from all patients. Result: Before treatment, serum iron, ferritin, transferrin saturation and triglycerides were significantly higher among HCV patients when compared to controls ( $\mathrm{p}<0.001$ ), while serum TIBC, transferrin, hepcidin, hepcidin/Ferritin ration, cholesterol were significantly lower in $\mathrm{HCV}$ patients in comparison with controls $(\mathrm{p}<0.001)$. Following treatment with DAAs, serum iron, ferritin, transferrin saturation and triglycerides were significantly decreased. On the other hand, serum TIBC, transferrin, hepcidin, hepcidin/Ferritin ration and serum cholesterol were significantly increased. The improvement of $\mathrm{HbA1c}$ was associated with an improvement in iron overload parameters. Conclusion: Rapid decrease in serum ferritin during IFN/RBV free treatment may reflect a quick regression of inflammation after inhibition of viral replication. The improvement in the iron parameters associated with improvement in triglyceride and glucose metabolism may also suggest an improvement of metabolic functions of the liver following HCV eradication.
\end{abstract}

Keywords: HCV, Hepcidin, Iron, Lipid, DAAs.

\section{INTRODUCTION}

Hepatitis $\mathrm{C}$ virus (HCV) is a blood-born pathogen and it is a significant global health concern in many countries including Egypt ${ }^{(1)}$. Following the acquisition of the virus, acute $\mathrm{HCV}$ infection can progress to chronic infection, which is associated with several morbidities, such as liver cirrhosis and cancer. HCVrelated morbidity strains healthcare systems worldwide, with approximately 71 million people chronically infected globally. Direct-acting antivirals (DAAs), a highly efficacious $\mathrm{HCV}$ treatment, can clear $\mathrm{HCV}$ infection and may substantially reduce disease burden (2). As such, global targets have been set by the World Health Organization (WHO) to eliminate $\mathrm{HCV}$ infection by $2030^{(3)}$.

Iron is an essential micronutrient for the human body. It has important roles in oxygen transport, oxidative phosphorylation and other enzymatic functions ${ }^{(4)}$. The liver produces the majority of proteins involved in iron metabolism including hepcidin and transferrin. The main characteristic of transferrin is its ability to reversibly bind iron which allows it to be a cellular iron donor or iron acceptor ${ }^{(5)}$.

Chronic HCV patients frequently develop mild to moderate iron overload ${ }^{(6)}$. Many experimental and clinical studies suggest that, excessive iron in chronic $\mathrm{HCV}$ is a cofactor promoting the progression of liver damage and increasing the risk of fibrosis, cirrhosis and $\mathrm{HCC}^{(6,7,8)}$. Elucidating the mechanism (s) of iron accumulation in chronic HCV may provide new tools for the management of chronic $\mathrm{HCV}$ or for the prevention of its complications or both. Many hypotheses have been advanced to explain the accumulation of iron in chronic HCV, including local release of iron from necrotic hepatocytes, incidental carriage of hemochromatosis mutations and $\mathrm{HCV}$ induced perturbation of liver iron homeostasis either directly or indirectly through immunologic and host response. With the discovery of hepcidin, the liver has emerged as the central organ in the regulation of systemic iron homeostasis ${ }^{(9)}$. Serum hepcidin and hepcidin/ferritin ratio were significantly lower in chronic HCV patients than negative persons (10). Following interferon therapy, both hepcidin and hepcidin / ferritin ratio were elevated ${ }^{(\mathbf{1 0})}$. Elevated serum ferritin level is common in patients with chronic $\mathrm{HCV}$ and predicts poor response to treatment with pegylated interferon and ribavirin ${ }^{(\mathbf{1 1})}$. Rapid decrease in serum ferritin during interferon/ ribavirin free treatment may reflect rapid regression of inflammation after inhibition of viral replication ${ }^{(\mathbf{1 1})}$.

Chronic infection causes iron accumulation by hepcidin suppression which has been proposed as major mechanism responsible for causing glucose intolerance by influencing insulin signaling. The accumulated iron causes increased glucose production by hepatocytes, increased fatty acid oxidation and decreased glucose oxidation in skeletal muscles and adipocytes and altered 
levels of adipokines in adipocytes. Furthermore, it causes oxidative stress, a factor independently responsible for causing insulin resistance.

The resultant hyperinsulinemia then causes rapid iron uptake by liver since insulin redistributes transferrin receptors from an intracellular compartment to cell membrane and further exacerbates iron overload (12,13,14,15). Exacerbation of oxidative stress by hepatocyte iron overload results in damage to the cell membranes, DNA instability and mutagenesis. The exacerbation of $\mathrm{HCV}$-induced oxidative stress with accompanying HCV-related impairment of antioxidant defense may promote hepatocarcinogenesis ${ }^{(7)}$.

\section{AIM OF THE WORK}

The aim of this study was to evaluate the iron metabolism dynamic changes in response to direct antiviral agents among Egyptian chronic HCV patients.

\section{PATIENTS AND METHODS}

This prospective cohort study was conducted on 180 subjects; 150 patients with chronic HCV who received different DAAs regimens at New Cairo Viral Hepatitis Treatment Center ${ }^{(16)}$, one of the Egyptian specialized HCV treatment facilities (Group A), in the period from January 2017 to September 2018. Regarding the given treatment regimens, twenty patients received paritaprevir $(150 \mathrm{mg})$, ombitasvir $(25 \mathrm{mg})$ and ribavirin, fifty-five patients received sofosbuvir $(400 \mathrm{mg})$ and daclatasvir $(60 \mathrm{mg})$, twenty patients received sofosbuvir $(400 \mathrm{mg})$ and simeprivir $(150 \mathrm{mg})$, and fifty-five patients received sofosbuvir $(400 \mathrm{mg})$, daclatasvir $(60 \mathrm{mg})$ and ribavirin. In addition, another thirty (30) healthy persons matched for age and sex were also included in the study as a control group (Group B).

\section{Ethical approval:}

The study was approved by the medical ethics committee of Al-Azhar University Hospitals and a written informed consent was obtained from all patients. Anti-viral treatments were chosen according to the standardized protocol issued by Egyptian National Committee for Control of Viral Hepatitis ${ }^{(17)}$.

All patients were subjected to routine pretreatment assessment including clinical evaluation, complete blood count, AST, ALT, bilirubin total and direct, serum albumin, prothrombin time and INR, anti-nuclear anti body, thyroid stimulating hormone, Abdominal ultrasonography, Fib-4 score, viral markers including $\mathrm{HCV}$ antibody by third generation enzyme linked immune sorbent assay (ELISA), hepatitis B surface antigen by third generation ELISA, and quantitative HCV RNA by PCR for group A patients (150 patients). As well as, serum iron, total iron binding capacity, ferritin, hepcidin, transferrin and alpha-fetoprotein, fasting blood sugar, total cholesterol, HDL, LDL and triglycerides. HbA1c for diabetic patients. The assessment during and at the end of treatment for chronic $\mathrm{HCV}$ patients include the following, serum iron, total iron binding capacity, ferritin, hepcidin, transferrin and alpha-fetoprotein, fasting blood sugar, total cholesterol, HDL, LDL and triglycerides for all patients will measure at weeks 4 and 12 after starting the treatment for all patients. HbA1c for diabetic patients only at 12 weeks in relation to DAAs.

\section{Statistical analyses}

Data were tabulated, coded then analyzed using the statistical package for social science (SPSS; Version 23.0; Chicago, IL, USA), where descriptive data reported as mean \pm Standard deviation (SD) and analyzed using $t$ student or $t$ paired. One-way analysis of variance (ANOVA) used to compare between more than two groups of numerical data. Statistical analysis included Pearson Correlation coefficient. A probability value ( $\mathrm{p}$ - value) $<0.05$ was considered statistically significant in all analyses.

\section{RESULTS}

The age of chronic HCV patients was $46.52 \pm$ (11.71) years and the age of healthy subjects was 47.97 \pm (11.45) years. No significant difference was seen between HCV patients and healthy subjects regarding age. Considering the complete blood count elements, liver function tests and kidney functions tests, there were statistically significant difference between both groups regarding platelet count, ALT and AST $(\mathrm{P}<$ 0.001 ). No significant difference was seen between HCV patients and healthy subjects regarding sex and diabetes mellitus prevalence Table (1).

Table (1): Baseline demographic and laboratory parameters of studied persons.

\begin{tabular}{|c|c|c|c|c|c|c|c|c|c|}
\hline & \multicolumn{2}{|c|}{ HCV $(n=150)$} & \multicolumn{2}{|c|}{ Healthy group $(n=30)$} & \multirow[t]{2}{*}{ Difference } & \multicolumn{2}{|c|}{$95 \% \mathrm{CI}$} & \multirow[b]{2}{*}{ t student } & \multirow[t]{2}{*}{$\mathbf{P}$} \\
\hline & Mean & \pm SD & Mean & \pm SD & & Lower & Upper & & \\
\hline Age & 46.52 & 11.711 & 47.97 & 11.455 & -1.45 & -6.05 & 3.16 & -0.620 & 0.536 \\
\hline BMI & 28.1256 & 3.450 & 29.247 & 5.131 & -1.12 & -3.59 & 1.35 & -0.897 & 0.371 \\
\hline $\mathbf{H b}$ & 13.793 & 1.0421 & 13.713 & 0.732 & 0.08 & -0.24 & 0.40 & 0.501 & 0.619 \\
\hline WBC & 6.256 & 1.207 & 7.0597 & 1.77091 & -0.80 & -1.66 & 0.05 & -1.847 & 0.066 \\
\hline PLT & 214.12 & 8.89 & 328 & 62.018 & -113.88 & -139.35 & -88.41 & -8.396 & $<0.001$ \\
\hline ALT(IU/L) & 50.06 & 5.797 & 27.33 & 2.692 & 23.82 & 17.39 & 30.25 & 7.310 & $<0.001$ \\
\hline AST(IU/L) & 49.08 & 3.919 & 25.07 & 5.356 & 24.50 & 18.59 & 30.41 & 8.176 & $<0.001$ \\
\hline Albumin $\mathrm{g} / \mathrm{dl}$ & 4.153 & 0.4707 & 4.237 & 0.2953 & -0.08 & -0.22 & 0.05 & -1.269 & 0.209 \\
\hline Bilirubin $\mathrm{mg} / \mathrm{dl}$ & 0.8049 & 0.039 & 0.6587 & 0.17988 & 0.1462 & 0.05434 & 0.23806 & 3.159 & 0.002 \\
\hline
\end{tabular}


Significant differences were found between HCV patients and healthy subjects regarding baseline serum iron, TIBC, transferrin saturation (TS), transferrin, ferritin, hepcidin and hepcidin/ ferritin (H/F) ratio (P < 0.001), (Table 2). Although the mean serum iron, TS and ferritin values were significantly higher in HCV patients, the TIBC, transferrin, hepcidin and H/F ratio values were significantly lower in HCV patients in comparison with healthy subjects. (Table 2). Significant differences were found between HCV patients and healthy subjects regarding baseline serum total cholesterol, HDL, LDL and triglyceride levels $(\mathrm{P}<0.001)$, (Table 2). Average total cholesterol, HDL and LDL values were significantly lower in HCV patients while the average triglyceride was significantly higher in $\mathrm{HCV}$ patients (table 2). The mean (SD) fasting blood sugar (FBS) value was $103.45(32.02) \mathrm{mg} / \mathrm{dl}$ among $\mathrm{HCV}$ patients and $96.87(9.62) \mathrm{mg} / \mathrm{dl}$ among healthy subjects (table 2). Yet HbA1c levels were7.88 (0.67) \% and 7.33(0.45) \% among HCV patients and healthy subjects respectively (Table 2).

Table (2): Baseline iron, lipid and sugar profiles of included subjects.

\begin{tabular}{|c|c|c|c|c|c|c|c|c|c|}
\hline & \multicolumn{2}{|c|}{ HCV $(n=150)$} & \multicolumn{2}{|c|}{ Non-HCV $(n=30)$} & \multirow[t]{2}{*}{ Difference } & \multicolumn{2}{|c|}{$95 \% \mathrm{CI}$} & \multirow[t]{2}{*}{ t student } & \multirow[t]{2}{*}{$\mathbf{P}$} \\
\hline & Mean & SD & Mean & SD & & Lower & Upper & & \\
\hline Iron $(\mu \mathrm{g} / \mathrm{dl})$ & 149.69 & 16.07 & 135.13 & 4.92 & 14.56 & 8.70 & 20.41 & 9.153 & $<0.001$ \\
\hline TIBC $(\mu \mathrm{g} / \mathrm{dl})$ & 319.79 & 24.25 & 349.27 & 8.89 & -29.48 & -38.34 & -20.60 & -11.513 & $<0.001$ \\
\hline TS \% & 47.28 & 7.46 & 38.70 & 1.34 & 8.58 & 5.88 & 11.28 & 13.043 & $<0.001$ \\
\hline $\begin{array}{c}\text { Transferrin } \\
\text { mg/dl }\end{array}$ & 243.64 & 28.06 & 277.47 & 16.07 & -33.83 & -44.28 & -23.38 & -9.088 & $<0.001$ \\
\hline $\begin{array}{c}\text { Ferritin } \\
\text { ng/ml }\end{array}$ & 267.39 & 9.03 & 95.70 & 22.15 & 171.69 & 138.99 & 204.39 & 20.466 & $<0.001$ \\
\hline $\begin{array}{l}\text { Hepcidin } \\
\mathrm{ng} / \mathrm{ml} \text {. }\end{array}$ & 5.81 & 1.55 & 11.05 & 1.74 & -5.24 & -6.00 & -4.48 & -10.775 & $<0.001$ \\
\hline H/F Ratio & 3.03 & 0.09 & 12.28 & 3.91 & -9.25 & -10.53 & -7.97 & -12.212 & $<0.001$ \\
\hline $\begin{array}{c}\text { Cholesterol } \\
\mathrm{mg} / \mathrm{dl}\end{array}$ & 163.67 & 18.56 & 176.00 & 8.26 & -12.33 & -16.57 & -8.08 & -5.764 & $<0.001$ \\
\hline HDL (mg/dl) & 39.38 & 3.06 & 43.97 & 3.03 & -4.59 & -5.79 & -3.38 & -7.514 & $<0.001$ \\
\hline LDL (mg/dl) & 92.99 & 17.51 & 105.96 & 8.75 & -12.97 & -17.24 & -8.71 & -6.053 & $<0.001$ \\
\hline LDL/HDL & 2.37 & 0.48 & 2.43 & 0.31 & -0.05 & -0.23 & 0.13 & -0.593 & 0.554 \\
\hline $\begin{array}{c}\text { Triglyceride } \\
\text { mg/dl }\end{array}$ & 156.53 & 13.37 & 130.37 & 13.46 & 26.17 & 20.88 & 31.45 & 9.775 & $<0.001$ \\
\hline $\begin{array}{l}\text { HbA1c* \% } \\
\text { for diabetic }\end{array}$ & 7.88 & 0.67 & 7.33 & 0.45 & 0.55 & -0.27 & 1.37 & 1.361 & 0.184 \\
\hline FBS $(\mathrm{mg} / \mathrm{dl})$ & 103.45 & 2.02 & 96.87 & 9.62 & 6.58 & 0.36 & 12.80 & 2.089 & 0.038 \\
\hline
\end{tabular}

There were significant changes in iron, TIBC, TS, transferrin, ferritin, hepcidin, and hepcidin/ ferritin levels after treating HCV patients with different regimens of DAAs $(\mathrm{P}<0.05)$, (Table 3). Notably these significant changes detected 1 month after starting treatment in all parameters of iron profile, moreover there were no significant difference between the various DAAs regimens regarding these iron profile changes $(\mathrm{P}>$ 0.05). Among $\mathrm{HCV}$ patients, iron significantly dropped from $149.69 \mathrm{microgram} / \mathrm{dl}$ at baseline to $147.01 \mathrm{microgram} / \mathrm{dl}$ and $135.40 \mathrm{microgram} / \mathrm{dl}, 1$ and 3 months after starting DAAs treatment respectively $(\mathrm{P}<0.05)$, (Table 3 ). TIBC significantly increased from $319.79 \mathrm{mg} / \mathrm{dl}$ at baseline to $323.18 \mathrm{mg} / \mathrm{dl}$, and $341.58 \mathrm{mg} / \mathrm{dl}, 1$ and 3 months after starting treatment respectively $(\mathrm{P}<$ 0.05), (Table 3). Transferrin saturation (TS) significantly dropped from $47.28 \%$ at baseline to $45.89 \%$ and $39.78 \%, 1$ and 3 months after starting treatment respectively $(\mathrm{P}<0.05)$, (Table 3 ). Transferrin significantly increased from 243.64 $\mathrm{mg} / \mathrm{dl}$ at baseline to $246.22 \mathrm{mg} / \mathrm{dl}$ and 254.07 $\mathrm{mg} / \mathrm{dl}, 1$, and 3 months after starting treatment respectively $(\mathrm{P}<0.05)$, (Table 3$)$. Serum ferritin significantly dropped from $267.39 \mathrm{ng} / \mathrm{dl}$ at baseline to $239.57 \mathrm{ng} / \mathrm{dl}$ and $166.80 \mathrm{ng} / \mathrm{dl}, 1$ and 3 months after starting treatment respectively $(\mathrm{P}<0.05)$, (Table 3). Hepcidin significantly increased from $5.80 \mathrm{ng} / \mathrm{dl}$ at baseline to $6.72 \mathrm{ng} / \mathrm{dl}$ and $10.01 \mathrm{ng} / \mathrm{dl}$, 1 and 3 months after starting treatment respectively $(\mathrm{P}<0.05)($ Table 3). Hepcidin/ ferritin $(\mathrm{H} / \mathrm{F})$ ratio significantly increased from 3.03 at baseline to 3.67 and 6.83, 1 and 3 months after starting treatment respectively $(\mathrm{P}<0.05)$, (Table 3). 
Table (3): Changes in Iron profile during DAAs therapy.

\begin{tabular}{|c|c|c|c|c|}
\hline & & Mean & \pm SD & $\begin{array}{c}\mathbf{P} \\
\text { (ANOVA) }\end{array}$ \\
\hline $\begin{array}{l}\text { Iron } \\
\mu \mathrm{g} / \mathrm{dl}\end{array}$ & $\begin{array}{l}\text { Baseline } \\
\text { (0) }\end{array}$ & 149.69 & 16.070 & $<0.001$ \\
\hline & $\begin{array}{l}\text { After 1 } \\
\text { month }\end{array}$ & \begin{tabular}{|l|}
147.01 \\
\end{tabular} & 14.522 & \\
\hline & $\begin{array}{l}\text { After } 3 \\
\text { months }\end{array}$ & 135.40 & 9.357 & \\
\hline $\begin{array}{l}\text { TIBC } \\
\mu \mathrm{g} / \mathrm{dl}\end{array}$ & $\begin{array}{l}\text { Baseline } \\
\text { (0) }\end{array}$ & 319.79 & 24.245 & $<0.001$ \\
\hline & $\begin{array}{l}\text { After 1 } \\
\text { month }\end{array}$ & 323.18 & 23.500 & \\
\hline & \begin{tabular}{|l|} 
After 3 \\
months \\
\end{tabular} & 341.58 & 15.737 & \\
\hline $\begin{array}{l}\text { TS } \\
\%\end{array}$ & $\begin{array}{l}\text { Baseline } \\
\text { (0) }\end{array}$ & 47.2835 & 7.456 & $<0.001$ \\
\hline & $\begin{array}{l}\text { After 1 } \\
\text { month }\end{array}$ & 45.8987 & 6.724 & \\
\hline & \begin{tabular}{|l|} 
After 3 \\
months
\end{tabular} & 39.7857 & 3.989 & \\
\hline $\begin{array}{c}\text { Transferrin } \\
\text { (TF) }\end{array}$ & $\begin{array}{l}\text { Baseline } \\
(0)\end{array}$ & 243.64 & 28.06 & 0.002 \\
\hline $\mathrm{mg} / \mathrm{dl}$ & $\begin{array}{l}\text { After 1 } \\
\text { month }\end{array}$ & 246.22 & 27.403 & \\
\hline & \begin{tabular}{|l|} 
After 3 \\
months
\end{tabular} & 254.07 & 23.397 & \\
\hline $\begin{array}{c}\text { Ferritin } \\
\mathrm{ng} / \mathrm{ml}\end{array}$ & $\begin{array}{l}\text { Baseline } \\
\text { (0) }\end{array}$ & 267.39 & 9.026 & $<0.001$ \\
\hline & $\begin{array}{l}\text { After 1 } \\
\text { month }\end{array}$ & 239.57 & 7.107 & \\
\hline & \begin{tabular}{|l|} 
After 3 \\
months
\end{tabular} & 166.80 & 5.308 & \\
\hline $\begin{array}{c}\text { Hepcidin } \\
\mathrm{ng} / \mathrm{ml}\end{array}$ & $\begin{array}{l}\text { Baseline } \\
\text { (0) }\end{array}$ & 5.809 & 1.545 & $<0.001$ \\
\hline & $\begin{array}{l}\text { After 1 } \\
\text { month }\end{array}$ & 6.720 & 1.180 & \\
\hline & \begin{tabular}{|l|} 
After 3 \\
months
\end{tabular} & 10.017 & 1.7749 & \\
\hline H/F Ratio & $\begin{array}{l}\text { Baseline } \\
\text { (0) }\end{array}$ & 3.0330 & 0.092 & $<0.001$ \\
\hline & \begin{tabular}{|l|} 
After 1 \\
month
\end{tabular} & 3.6785 & 0.212 & \\
\hline & $\begin{array}{l}\text { After 3 } \\
\text { months }\end{array}$ & 6.8391 & 1.050 & \\
\hline
\end{tabular}

Among the chronic HCV patients, the mean baseline values of serum iron, TS and ferritin were significantly higher in diabetics than non-diabetics. On the other hand, non-diabetics had significantly higher TIBC, transferrin, hepcidin and $\mathrm{H} / \mathrm{F}$ ratio (figure 1). No significant changes detected in iron and ferritin levels three months after starting DAAs treatment between diabetic and non-diabetic $\mathrm{HCV}$ patients $(\mathrm{P}>0.05)$, (figure 1). Although there is an improvement in the TIBC, transferrin, TS, hepcidin and $\mathrm{H} / \mathrm{F}$ ratio in the both groups but still improvement in non-diabetic patients more significantly than diabetic patients three months after starting DAAs treatment $(\mathrm{P}<0.05)$, (figure 1).

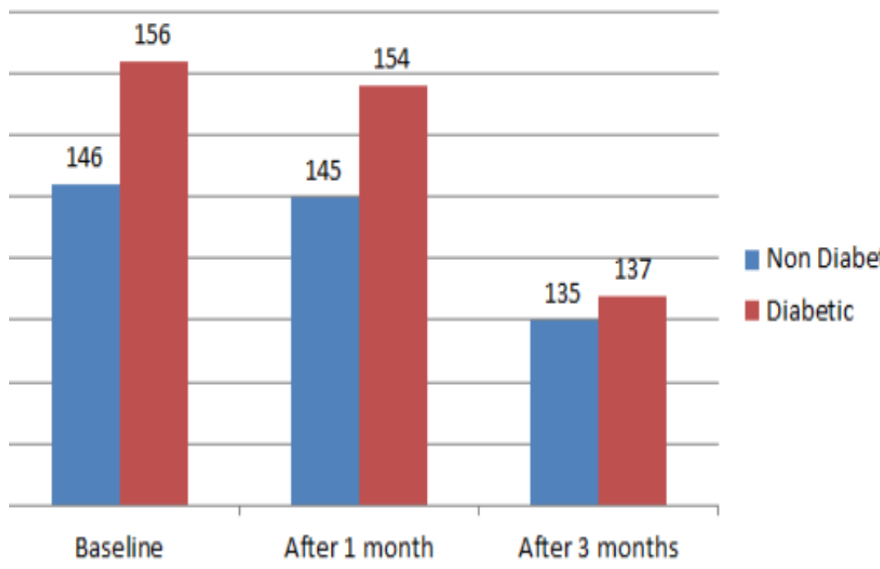

Figure (1): Changes of serum iron level in chronic HCV patients before and after DAAs in diabetic and non-diabetic patients

All lipid profile parameters were significantly changed after DAAs treatment in chronic HCV patients. Total Cholesterol (TC) significantly increased from $163.67 \mathrm{mg} / \mathrm{dl}$ at baseline to $165.95 \mathrm{mg} / \mathrm{dl}$ and $185.39 \mathrm{mg} / \mathrm{dl}, 1$ and 3 months after treatment respectively $(\mathrm{P}<0.05)$, (Table 4). HDL significantly increased from 39.38 $\mathrm{mg} / \mathrm{dl}$ at baseline to $39.85 \mathrm{mg} / \mathrm{dl}$ and $41.40 \mathrm{mg} / \mathrm{dl} 1$ and 3 months after treatment respectively ( $\mathrm{P}<$ 0.05 ), (table 4). LDL significantly increased from 92.987 at baseline to $95.385 \mathrm{mg} / \mathrm{dl}$ and 119.61 $\mathrm{mg} / \mathrm{dl} 1$ and 3 months after treatment respectively $(\mathrm{P}<0.05)$, (Table 4).

LDL/HDL significantly increased from 2.37 at baseline to 2.40 and 2.901 and 3 months after treatment respectively $(\mathrm{P}<0.05)$, (table 4). Triglyceride (TG) significantly decreased from $156.53 \mathrm{mg} / \mathrm{dl}$ at baseline to $153.57 \mathrm{mg} / \mathrm{dl}$ and $121.84 \mathrm{mg} / \mathrm{dl} 1$ and 3 months after treatment respectively $(\mathrm{P}<0.05)$, (table 4$)$. Among chronic HCV patients $(n=150)$, fasting Blood Sugar (FBS) significantly decreased from $103.45 \mathrm{mg} / \mathrm{dl}$ at baseline to $94.61 \mathrm{mg} / \mathrm{dl}$ and $86.89 \mathrm{mg} / \mathrm{dl} 1$ and 3 months after treatment respectively $(\mathrm{P}<0.05)$. Moreover, among diabetics $(n=22)$, HbA1c significantly 
ejhm.journals.ekb.eg

Table (4): Changes in lipid and glucose profiles during DAAs therapy.

\begin{tabular}{|c|c|c|c|c|}
\hline 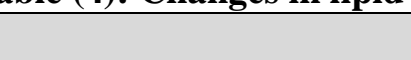 & & Mean & \pm SD & P (ANOVA) \\
\hline \multirow{3}{*}{$\begin{array}{c}\mathrm{TC} \\
\mathrm{mg} / \mathrm{dl}\end{array}$} & Baseline (0) & 163.67 & 18.565 & \multirow[t]{3}{*}{$<0.001$} \\
\hline & After 1 month & 165.95 & 18.138 & \\
\hline & After 3 months & 185.39 & 18.300 & \\
\hline \multirow{3}{*}{$\begin{array}{l}\text { HDL } \\
\mathrm{mg} / \mathrm{dl}\end{array}$} & Baseline (0) & 39.38 & 3.056 & \multirow[t]{3}{*}{$<0.001$} \\
\hline & After 1 month & 39.85 & 2.875 & \\
\hline & After 3 months & 41.40 & 2.546 & \\
\hline \multirow{3}{*}{$\begin{array}{l}\text { LDL } \\
\mathrm{mg} / \mathrm{dl}\end{array}$} & Baseline (0) & 92.987 & 17.5099 & \multirow[t]{3}{*}{$<0.001$} \\
\hline & After 1 month & 95.385 & 17.2031 & \\
\hline & After 3 months & 119.619 & 18.6168 & \\
\hline \multirow{3}{*}{$\begin{array}{c}\text { LDL/HDL } \\
\mathrm{mg} / \mathrm{dl}\end{array}$} & Baseline (0) & 2.3732 & 0.4786 & \multirow[t]{3}{*}{$<0.001$} \\
\hline & After 1 month & 2.4058 & 0.4709 & \\
\hline & After 3 months & 2.9037 & 0.5061 & \\
\hline \multirow{3}{*}{$\underset{\mathrm{mg} / \mathrm{dl}}{\mathrm{TG}}$} & Baseline (0) & 156.53 & 13.370 & \multirow[t]{3}{*}{$<0.001$} \\
\hline & After 1 month & 153.57 & 12.626 & \\
\hline & After 3 months & 121.84 & 13.795 & \\
\hline \multirow{3}{*}{$\begin{array}{c}\text { FBS } \\
\mathrm{mg} / \mathrm{dl}\end{array}$} & Baseline (0) & 103.45 & 32.133 & \multirow[t]{3}{*}{$<0.001$} \\
\hline & After 1 month & 94.61 & 19.391 & \\
\hline & After 3 months & 86.89 & 8.269 & \\
\hline \multirow[t]{2}{*}{ HbA1C \% for diabetics } & Baseline (0) & 7.879 & 0.6742 & \multirow[t]{2}{*}{$<0.001$} \\
\hline & After 3 months & 6.738 & 0.6304 & \\
\hline
\end{tabular}

Before starting treatment, ferritin had strong negative correlation with hepcidin and hepcidin/ ferritin ratio $(\mathrm{P}<0.05)$. At the end of treatment, iron had strong positive correlation with ferritin and strong negative correlation with hepcidin $(\mathrm{P}<0.05)$, while, ferritin had strong negative correlation with hepcidin. Triglyceride (TG) and HDL had strong correlation with irons profile parameters. At baseline TG had strong positive correlation with iron, TS and ferritin (P $<0.05)$. On the other hand, TG had strong negative correlation with transferrin, TIBC, hepcidin and H/F ratio at baseline $(\mathrm{P}<0.05)$. Although $\mathrm{TG}$ had strong positive correlation with iron, ferritin and TS (P < 0.05 ), it had strong negative correlation with TIBC and hepcidin, 3 months after DAAs therapy $(\mathrm{P}<0.0)$. HDL had strong positive correlation with transferrin, TIBC, hepcidin and $\mathrm{H} / \mathrm{F}$ Ratio at baseline $(\mathrm{P}<0.05)$ and strong negative correlation with TS and Ferritin at baseline $(\mathrm{P}<0.05)$. Among chronic HCV patients (n $=150$ ) FBS at baseline had strong positive correlation with TS levels. FBS had strong negative correlation with hepcidin at baseline. Among diabetic patients ( $\mathrm{n}=$ 22) $\mathrm{HbA} 1 \mathrm{C}$ at baseline had strong positive correlation with iron and TS levels. At the end of treatment FBS had significant negative correlation with TIBC, transferrin, hepcidin and $\mathrm{H} / \mathrm{F}$ ratio $(\mathrm{P}<0.05)$.

Among chronic HCV patient's platelet count had strong positive correlation with TIBC, hepcidin, H/F ratio and transferrin at baseline, and strong negative correlation with iron, TS and ferritin. FIB4 score had positive correlation with iron, TS and ferritin, and strong negative correlation with TIBC, hepcidin, H/F ratio and transferrin at baseline. AST at baseline positively correlated with iron, TS and ferritin, and negatively correlated with Hepcidin \& H/F ratio.

\section{DISCUSSION}

A significant proportion (34.48\%) of untreated chronic HCV patients had iron overload ${ }^{(18)}$. This finding was reported by multiple studies from geographic regions with different HCV genotypes ${ }^{(\mathbf{1 9})}$. According to the present results, chronic $\mathrm{HCV}$ patients had iron overload, which is in concordance with the above findings. In contrast to our results, other studies reported that chronic $\mathrm{HCV}$ patients had no significant increase in the serum iron levels, but most of these studies tested small samples of chronic HCV patients $(\mathbf{1 0 , 2 0}, \mathbf{2 1}, \mathbf{2 2 )}$. Notably, all of them showed significant elevation of serum ferritin levels in chronic HCV patients.

Significant decrease of serum iron levels was reported after pegylated interferon-alfa (PEG-IFN)ribavirin therapy by some investigators ${ }^{(23)}$, as well as after DAAs ${ }^{(24)}$. Hemaida and his colleagues ${ }^{(25)}$ found that serum iron overload showed more significant improvement with sofosbuvir/ ledipasvir combination therapy compared with sofosbuvir /daclatasvir. Although significant decrease of iron load detected in our patients after DAAs, no significant difference of serum iron levels was detected between different DAAs regimens. In contrast to the present results, Carvalho et al. ${ }^{(26)}$, found that, no significant variations were found in serum iron after treatment with the new DAAs. The baseline serum ferritin was significantly 
higher in our chronic HCV patients confirming the previous results $(\mathbf{1 9 , 2 0 , 2 5 )}$.

In the current study, marked improvement of the baseline serum ferritin was detected in chronic HCV patients at the end of treatment with different DAAs regimens. Several reports showed the same improvement in the baseline ferritin both at the end of DAAs treatment (27), and at attaining sustained virological response at 12 weeks (SVR 12) ${ }^{(24,26)}$. This indicates the durability of serum ferritin improvement after stoppage of treatment. In the study conducted by Hemaida et al. ${ }^{(25)}$, they reported that, serum ferritin showed more significant improvement with sofosbuvir/ ledipasvir combination therapy than sofosbuvir/daclatasvir combination therapy. We could not find any significant difference in ferritin levels among different DAAs regimens. Likewise, Bazeed et al. ${ }^{(23)}$, reported that serum ferritin level was significantly decreased in all patients after treatment with different DAAs regimens.

Serum hepcidin levels reflects the liver functional status, liver fibrosis and metabolic functions in chronic HCV patients (28). The baseline serum hepcidin levels was significantly lower in our chronic HCV patients. This was in agreement with other reports ${ }^{(\mathbf{1 0}, \mathbf{1 9}, \mathbf{2 0})}$. This lower hepcidin level had strong negative correlation with triglycerides, FBS, AST level and FIB 4 and strong positive correlation with platelet count. Interestingly, serum hepcidin levels significantly increased at the end of treatment in patients whom gained SVR. Moreover, this improvement of serum hepcidin levels associated with significant improvement in triglyceride level and FBS. Taking together, this data suggested that viral response in our patients is associated with improved liver synthetic function of hepcidin, improved triglycerides metabolic function as well as glucose metabolic function in the liver. The significant increase of hepcidin level in response to PEG-INF/ ribavirin therapy previously reported ${ }^{(\mathbf{1 0})}$. According to our results marked improvement of hepcidin levels was observed in patients whom responded to DAAs therapy. In the present work, no significant improvement was detected among non-responder. This observation highlights the importance role of $\mathrm{HCV}$ in modulation of hepcidin expression and its consequences on increased iron overload in those patients. Moreover, it suggests the hepcidin levels as a marker of improvement in chronic $\mathrm{HCV}$ patients undergoing DAAs therapy. Indeed, a better understanding of hepcidin dynamic changes in $\mathrm{HCV}$ patients may potentiate the antiviral effect in chronic $\mathrm{HCV}$ patients.

Type 2 diabetes mellitus duo to insulin resistance is extremely common in patients with chronic hepatitis $\mathrm{C}^{(\mathbf{1 4})}$. Hepatic iron overload produces oxidation stress, a factor responsible for $\mathrm{HCV}$ associated insulin resistant ${ }^{(29)}$. Iron overload can worsen insulin resistant by interfering with insulin receptor signaling and inhibiting the ability to burn carbohydrates in the liver and muscle. It is well documented that liver and peripheral IR increase, and pancreatic insulin secretion decrease as level of body iron rises ${ }^{(30)}$. The baseline serum iron and ferritin as well as hepcidin were significantly different between diabetic and nondiabetic HCV patients in our cohort study. Indeed, iron overload was significantly higher among diabetic patients. Significant improvement of HbAlc detected in HCV patients responded to antiviral therapy and this agrees with Dawood et al. ${ }^{(31)}$ and Salomone et al. (32). Interestingly, the improvement of $\mathrm{HbAlc}$ associated with improvement of iron overload parameters in our patients, supporting the potential role of iron overload on occurrence of HCV related insulin resistant. Moreover, these results infer the added benefit of HCV eradication after DAAs therapy in improvement of hyperglycemia.

The average total cholesterol, HDL and LDL values, were significantly lower in HCV group in comparison to control group while average triglycerides were significantly higher in HCV group. The same finding was reported by El Sagheer and his colleagues ${ }^{(33)}$, which could highlight the complex metabolic alterations in chronic HCV infection.

The changes in lipid profile after therapy represented an interesting finding, total cholesterol, HDL, LDL and LDL/HDL ratio, significantly increased over the study follow up visits. However, triglycerides significantly decreased over the same study visits. The same findings were reported by other studies ${ }^{(33,34)}$.

This study had some limitations like the shortterm follow-up period which made it difficult to predict the durability of such changes in iron, lipid and glucose metabolism. Also, calculation of the insulin resistance could add data about the possible mechanisms of blood sugar improvement in those patients. Because of the high efficacy of DAAs, a minority of our patients were non responders, and this made it impossible to compare the impact of nonresponse to therapy on the studies parameters.

\section{CONCLUSION}

In conclusion, patients with chronic HCV seem to have elevated serum iron markers, which may worsen liver injury in which low serum level of hepcidin may play a role. After successful therapy of HCV with DAAs, the rapid decrease of serum ferritin may reflect rapid regression of inflammation duo to inhibition of viral replication. Successful therapy of HCV patients with DAAs could result in restoration of serum hepcidin concentration to normal value which suggests a direct effect of $\mathrm{HCV}$ eradication on iron homeostasis. The change in iron parameters was 
associated with an improvement in triglyceride and glucose metabolism which could reflect an improvement of metabolic function of the liver. Patients who have achieved SVR have increased serum levels of cholesterol and LDL and may have increased risk of cardiovascular outcomes due to development of hyperlipidemia.

\section{REFERENCES}

1. El Kassas M, Elbaz T, Elsharkawy A et al. (2018): HCV in Egypt, prevention, treatment and key barriers to elimination. Expert Rev Anti Infect Ther., April;16(4):345-350.

2. Elbaz T, El-Kassas M, Esmat G (2015): New era for management of chronic hepatitis $\mathrm{C}$ virus using direct antiviral agents: A review. J Adv Res., 6(3):301-10.

3. Al Kanaani Z, Mahmud S, Kouyoumjian SP et al. (2018): The epidemiology of hepatitis $\mathrm{C}$ virus in Pakistan: systematic review and meta-analyses. R Soc Open Sci., 5 (4)180257.

4. Anderson ER, Shah YM (2013): Iron homeostasis in the liver. Compr Physiol., 3 (1): 315-30.

5. Munoz M, Villar I, Garcia-Erce JA (2009): An update on iron physiology. World J Gastroenterol., 15 (37): 4617-26.

6. Guyader D, Thirouard AS, Erdtmann L et al. (2007): Liver iron is a surrogate marker of severe fibrosis in chronic hepatitis C. J Hepatol., 46(4): 587-595.

7. Sikorska K, Bernat A (2014): Iron homeostasis and its regulators over the course of chronic hepatitis C. Future Virol., 9(9):831-846.

8. Koji U, Ryosuke T, Naoto F et al. (2016). Impact of serum ferritin level on hepatocarcinogenesis in chronic hepatitis $\mathrm{C}$ patients. Hepatology Research, 46: 259-268.

9. Pietrangelo A (2007): Hemochromatosis: an endocrine liver disease. Hepatology, 46(4): 1291-1301.

10. Marzouk HA, Azayed N, Al-Ansary M et al. (2013): Hepcidin levels in Egyptian patients with chronic hepatitis C. World Appl Sci., 22(8):1140-1145.

11. Stern R, Kozbial K, Freissmuth C et al. (2016): Decrease of hyperferritinemia in chronic hepatitis $\mathrm{C}$ patients due to IFN/RBV free antiviral treatment. Z Gastroenterol., 54- P86.

12. Hina A, Umbreen A, Shahid A et al. (2017): Association of hepcidin with hepatitis $\mathrm{C}$ induced diabetes mellitus. Journal of Rawalpindi Medical College, 21(1): 13-15.

13. Ali ST and Mohamed NA (2019): Inadequate serum hepcidin levels in chronic hepatitis $C$ infection-induced type 2 diabetes mellitus. Sci J Al-Azhar Med Fac Girls., 3 (1):91-96.

14. El-Zayadi AR, Anis M (2012): Hepatitis $C$ virus induced insulin resistance impairs response to anti-viral therapy. World J Gastroenterol., 18(3): 212-224.

15. Basuli D, Stevens RG, Torti FM et al. (2014): Epidemiological associations between iron and cardiovascular disease and diabetes. Front Pharmacol., 5:117-120.

16. El Kassas M, Alboraie M, Omran D et al. (2018): An account of the real-life hepatitis $\mathrm{C}$ management in a single specialized viral hepatitis treatment center in Egypt: results of treating 7042 patients with 7 different direct acting antiviral regimens. Expert Rev Gastroenterol Hepatol., 24:1-8

17. El-Akel W, El-Sayed MH, El Kassas M et al. (2017): National treatment programme of hepatitis C in Egypt: Hepatitis C virus model of care. J Viral Hepat., 24(4):262-267.

18. Lin TJ, Lin CL, Wang CS et al. (2005): Prevalence of HFE mutations and relation to serum iron status in patients with chronic hepatitis with nonalcoholic fatty liver disease in Taiwan. World J Gastroenterol., 11(25):3905-3908.

19. Radicheva MP, Andonova AN, Milcheva HT et al. (2018): Serum markers of iron metabolism in chronic liver diseases. Open Access Maced J Med Sci., 20: 6(6): 1010-1016.

20. El Lehleh AM, El Shazly RA, Hamza RR (2017): Study of serum hepcidin in patients with chronic hepatitis $\mathrm{C}$. Menofiya Medical Journal, 30 (3): 721-726.

21. Fujita N, Sugimoto R, Motonishi S et al. (2008): Patients with chronic hepatitis $\mathrm{C}$ achieving a sustained virological response to peginterferon and ribavirin therapy recover from impaired hepcidin secretion. J. Hepatol., 49(5): 702-710.

22. El Wakil R, Mokhles M, Tohamy A et al. (2012): Hepcidin and chronic hepatitis c: Exploring the controversy. Australian Journal of Basic and Applied Sciences, 6(13): 558-565.

23. Bazeed FB, Elsayed EH, Abd El-Aziz AA (2016): Evaluation of serum iron and ferritin in different treatment regimens for chronic hepatitis $\mathrm{C}$ virus. Journal of Pharmacy and Biological Sciences, 11 (4): 13-19.

24. Bernuth S, Yagmur E, Schuppan D et al. (2016): Early changes in dynamic biomarkers of liver fibrosis in hepatitis $\mathrm{C}$ virus-infected patients treated with sofosbuvir. Digestive and Liver Disease, 48(3): 291-297.

25. Hemaida KH, Kayser HH, Mohamed RS et al. (2018): Role of S-iron and ferritin to predict the response to recent new antiviral treatment in chronic hepatitis $\mathrm{C}$ patients. Egyptian Journal of Hospital Medicine, 70 (9): 1518-1528.

26. Carvalho JR, Velosa J, Serejo F (2018): Lipids, glucose and iron metabolic alterations in chronic hepatitis $\mathrm{C}$ after viral eradication - comparison of the new direct-acting antiviral agents with the old regimens. Scandinavian Journal of Gastroenterology, 53(7):857-863.

27. Chu P, Nakamoto $\mathbf{N}$, Ugamura A (2016). Degree of normalization of hyperferritinemia by the end of IFN- free DAA for chronic hepatitis $\mathrm{C}$ patients is predictive of early post- treatment emergence of HCC. Hepatology, 64 (1): 765.

28. Jaroszewicz J, Rogalska M , Flisiak $R$ (2008): Serum prohepcidin reflects the degree of liver function impairment in liver cirrhosis. Biomarkers, 13(5):478-85.

29. Mitsuyoshi H, Itoh Y, Sumida Y et al. (2008): Evidence of oxidative stress as a cofactor in the development of insulin resistance in patients with chronic hepatitis C. Hepatol Res., 38(4):348-353.

30. Datz C, Felder TK, Niederseer D et al. (2013): Iron homeostasis in the metabolic syndrome. Uer J Clin Invest., 43(2): 215-24.

31. Dawood AA, Nooh MZ, Elgamal AA (2017): Factors associated with improved glycemic control by direct-acting antiviral agent treatment in Egyptian type 2 diabetes mellitus patients with chronic hepatitis $C$ genotype 4 . Diabetes and Metabolism, 41(4):316-321.

32. Salomone F, Catania M, Montineri A et al. (2018): Hepatitis C virus eradication by direct antiviral agents improves glucose tolerance and reduces post-load insulin resistance in nondiabetic patients with genotype 1 . Liver International., 38(7):1206-1211.

33. El Sagheer G, Soliman E, Ahmed A et al. (2018): Study of changes in lipid profile and insulin resistance in Egyptian patients with chronic hepatitis C genotype 4 in the era of DAAs. Libyan Journal of Medicine, 13 (1): 143-144.

34. Kanda T and Moriyama M (2017): Direct-acting antiviral agents against hepatitis $\mathrm{C}$ virus and lipid metabolism. World $\mathrm{J}$ Gastroenterol., 23(31): 5645-5649. 